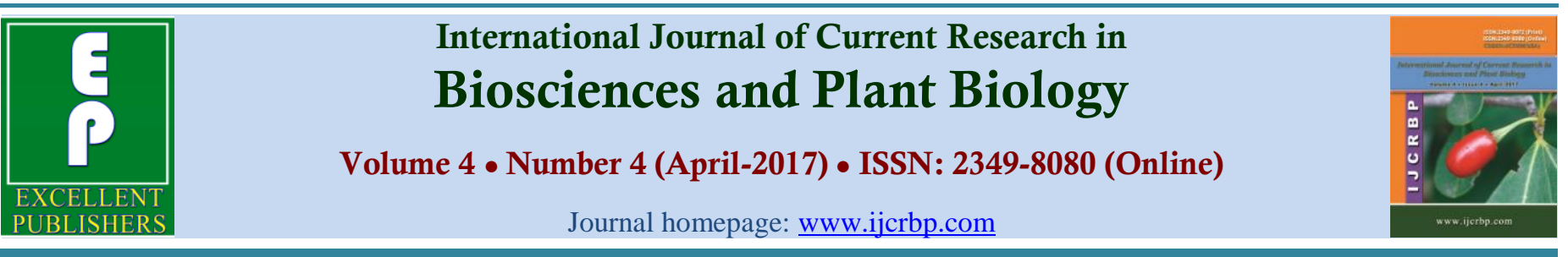

\title{
Pedological Characterization and Fertility Evaluation of Paddy Soils of Mvumi Village, Kilosa District, Tanzania
}

\author{
Ikunda H. Massawe*, Balthazar M. Msanya and Filbert B. Rwehumbiza
}

Department of Soil and Geological Sciences, College of Agriculture, Sokoine University of Agriculture, P.O. Box 3008, Morogoro, Tanzania

*Corresponding author.

\begin{abstract}
This study was conducted to characterize, classify and evaluate fertility of soils of Mvumi Village, Kilosa District, Tanzania. Representative soil profile of the colluvio-alluvial plain covering Mvumi Village was identified, dug, described and sampled using FAO Guidelines. Four samples from genetic horizons and eight surface samples from eight farms were taken for pedological characterization and soil fertility evaluation respectively. Results on pedon morphology revealed very deep and moderately well drained to somewhat poorly drained profile with very dark grey clays and granular topsoil structure over weak coarse wedge-shaped subsoil structure. The pedon was classified as Ustic Endoaquerts and Haplic Vertisols respectively in USDA Soil Taxonomy and WRB for Soil Resources. Shrinking and swelling, and pedoturbation were typical pedogenic processes. Low pedon $\mathrm{Ca} / \mathrm{Mg}$ ratios indicate nutrient imbalance likely to limit uptake of $\mathrm{Mg}$ by plants. Very high $\mathrm{Mg} / \mathrm{K}$ ratios can also lead to nutrient imbalance and toxicity. All sampled farm sites had clayey texture and $\mathrm{pH}$ ranging from 5.2 to 7.4 . OC $(0.53-1.75 \%)$ was low in all sites. $\mathrm{N}(0.06-0.19 \%), \mathrm{P}\left(1.54-5.79 \mathrm{mg} \mathrm{P} \mathrm{kg}^{-1}\right)$ and $\mathrm{K}(0.12-0.40 \mathrm{cmol}$ $\left.(+) \mathrm{kg}^{-1}\right)$ were deficient whereas micronutrients were adequate in all sites except for $\mathrm{Zn}$ $\left(0.35-1.57 \mathrm{mg} \mathrm{kg}^{-1}\right)$ which was low. CEC was rated as medium (15.2 to $21.6 \mathrm{cmol}$ $(+) / \mathrm{kg}$ ). Based on landform features and soil properties of both pedon and surface samples, soils of Mvumi were recommended for paddy rice as one of major crops. Prudent fertilizer use is deemed necessary to address possible deficiency and imbalance of some nutrient elements.
\end{abstract}

\section{Introduction}

A proper choice of soil and water management strategies is important in improving agricultural production. Thorough understanding of the type and fertility status of soil helps in choosing the appropriate soil and water management systems (Karuma et al., 2014). Thus, soil

\section{Article Info}

Accepted: 28March 2017

Available Online: 06 April 2017

\section{Keywords}

Nutrients

Paddy soils

Pedological characterization

Soil fertility evaluation

and related land resources inventory and characterization are basic in guiding and enabling forecast of land use potential and management requirements for sustained agricultural production (Msanya et al., 2016). Pedological characterization provides valuable information and knowledge on soil characteristics and gives clear understanding on soil 
genesis, morphology, classification and spatial distribution of soils in an area (Kebeney et al., 2015). The types and amount of fertilizers to be applied for economic and sustainable crop production depend on knowledge about the soil (Msanya et al., 2016). The information on type of soil is obtained through detailed biophysical characterization of the soils (Msanya et al., 2003) including laboratory analysis of chemical and physical properties of the soil which helps to understand the fertility status of the soil.

Mvumi Village in Kilosa District is known for its importance as far as agriculture is concerned. The smallholder farmers in this area depend on pastoralism, rice and maize production for their livelihood. All these activities depend on soil and related land resources. It is therefore important to study and characterize the soils of this area so as to generate information that will guide proper and sustainable soil and water management.

There have been number of studies that were carried out in Morogoro Region to characterize the soils of this region (Msanya et al., 2001; Msanya et al., 2003). The information that was obtained in these studies was centred in other specific areas and cannot be used in forecasting the potential and limitations of soils of Mvumi Village. Therefore the current study was undertaken specifically at Mvumi Village, Kilosa District in Tanzania with the aim of generating the soil information needed for soil and water management in the study area, thereby improving agricultural production. The specific objectives of this study were: (i) to carry out pedological characterization of soils of Mvumi Village where paddy is grown (ii) to classify the soils of Mvumi Village by using the 'United States Department of Agriculture (USDA) Soil Taxonomy' and the 'World Reference Base for Soil Resources' scheme of classification and (iii) to carry out soil fertility evaluation of the soils of Mvumi Village for paddy rice production.

\section{Materials and methods}

\section{Description of the study area}

The centre of Mvumi Village lies at latitude06 $35^{\prime} 48.9^{\prime \prime}$ South and longitude $37^{\circ} 13^{\prime} 31.5^{\prime \prime}$ East with elevation of $413 \mathrm{~m}$ above sea level. The study site is located about 46 $\mathrm{km}$ from Dumila Town. The soil parent material at the site is alluvium derived from Gongwe Mountains. The site has a slope gradient of $0.5 \%$. When dry, the surface is characterized by wide deep cracks extending from surface to more than $50 \mathrm{~cm}$ depth implying the dominance of 2:1 silicate clays in the soils. No erosion signs were observed in the area but deposition occurs due to flooding during the rainy season. The soils are moderately well drained to somewhat poorly drained.

The climate of the area is characterized by a largely monomodal rainfall pattern consisting of a warm rainy season from October to May with its peak in April (Fig. 1). Annual rainfall ranges from $532.4 \mathrm{~mm}$ to $1536.8 \mathrm{~mm}$. Very little rain occurs from June to October. During the rainy period of six months (December till May), $80 \%$ of the mean annual precipitation occurs, with moderate reduction of rainfall in February. The maximum temperature varies between $29.2^{\circ} \mathrm{C}$ to $31.8^{\circ} \mathrm{C}$ and minimum temperature ranges between $20^{\circ} \mathrm{C}$ to $24.2^{\circ} \mathrm{C}$ (Fig. 2). Agricultural activities in the study area are dominated by rice cultivation which is grown both as a food and cash crop.

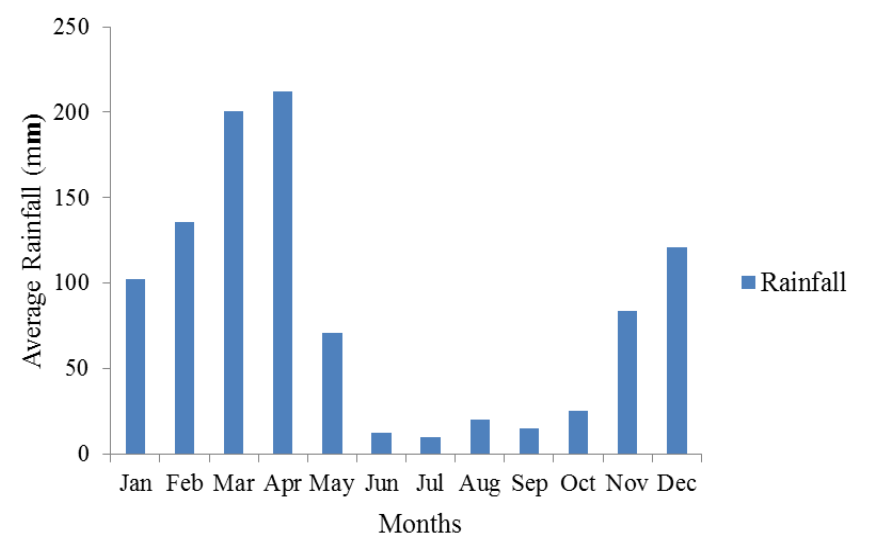

Fig. 1: Mean monthly rainfall data of the study site (20072015).

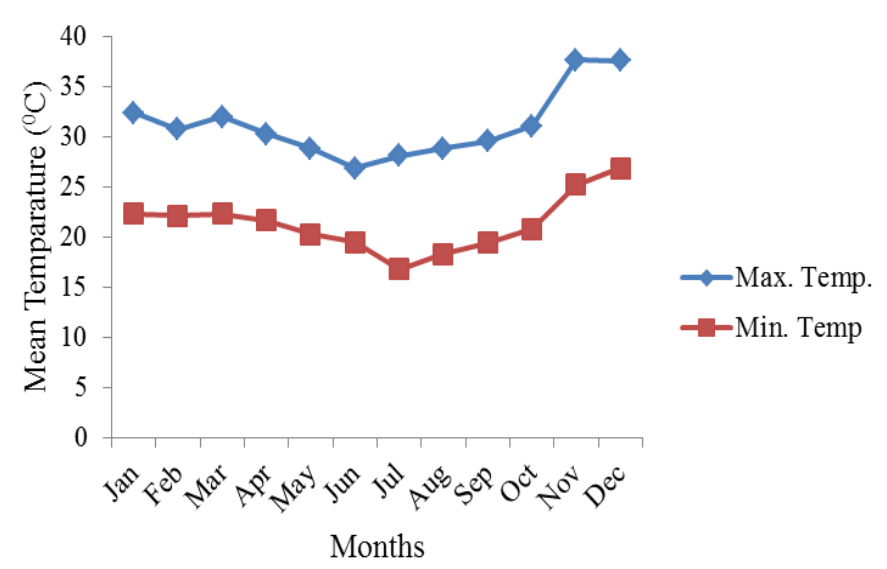

Fig. 2: Mean monthly maximum and minimum temperatures of the study site (2007-2015). 


\section{Pedological characterization and soil sampling}

Reconnaissance survey was conducted by using transect walks, auger observation and description to establish representative study sites on the basis of landforms and other physiographic attributes. A soil pit was dug measuring $3 \mathrm{~m}$ wide, $5 \mathrm{~m}$ in long and $2 \mathrm{~m}$ deep, and was described according to the standard guidelines by FAO (2006). Geo-referencing of the profile was done using Garmin Global Positioning System (Model etrex 20). Soil color was determined using Munsell Color Charts (Munsell Color Company, 1992).Penetration resistance of each identified horizon was measured using Japanese Penetrometer Model DKI-5551 of Daiki Rika Kogyo Company. The following formula was used to calculate penetration resistance in $\mathrm{kg} \mathrm{cm}^{-2}$ :

Penetration resistance $\left(\mathrm{kg} \mathrm{cm}^{-2}\right)=(100 * \mathrm{X}) / 0.7952(40-\mathrm{X})^{2}$

Where,

$\mathrm{X}=\mathrm{mm}$ of Penetrometer reading

Data were entered onto field description forms designed following the FAO Guidelines for Soil Description (FAO, 2006) and samples (disturbed) from each genetic horizon (weighing $1 \mathrm{~kg}$ ) were collected. Undisturbed $100 \mathrm{cc}$ core samples were collected from three sections of the profile (i.e. $0-5 \mathrm{~cm}, 45-50 \mathrm{~cm}$ and $95-100$ $\mathrm{cm})$.Soil samples were carried to the Department of Soil and Geological Sciences Laboratory of Sokoine University of Agriculture for analysis to generate data required for general pedological characterization soil classification.

\section{Soil sampling for fertility evaluation}

Using soil auger, eight surface $(0-30 \mathrm{~cm}$ depth) samples from eight rice farms (four from the farms inside the irrigation scheme and four from farms outside the irrigation scheme) were collected from four sampling spots in each farm. The four sub-samples collected from sampling spots in each farm were mixed and quartered to obtain representative composite samples of $1 \mathrm{~kg}$ for laboratory analysis. The samples were also carried to the Department of Soil and Geological Sciences Laboratory for analysis,

\section{Soil analysis for pedological characterization and fertility evaluation}

Disturbed profile and fertility soil samples from the field were first dried and ground to pass through $2 \mathrm{~mm}$ sieve to obtain fine earth fractions. Sieved samples were labelled and packed for analysis of various soil physical and chemical characteristics.

Undisturbed core samples were used for determination of bulk density (BD) and soil moisture retention characteristics. Bulk density was measured using gravimetric method by weighing soil cores after drying to constant weight at $105^{\circ} \mathrm{C}$ (Blake and Hartge, 1986). Disturbed soil samples were used for determination of other physical and chemical properties. Particle size analysis was determined by hydrometer method (Day, 1965) after dispersion with 5\% sodium hexametaphosphate and textural classes were determined using the USDA textural class triangle (USDA Soil Taxonomy, 1975).

Soil $\mathrm{pH}$ was measured potentiometrically in water and in $1 \mathrm{~N} \mathrm{KCl}$ at the ratio of 1:2.5 soil:water and soil: $\mathrm{KCl}$ (McLean, 1986), respectively. Organic carbon (OC) was determined by the Walkley and Black wet oxidation method as described by Nelson and Sommers (1982) and organic matter $(\mathrm{OM})$ was determined by multiplying by a factor of 1.724 values of organic carbon obtained (Duursma and Dawson, 1981).

Total $\mathrm{N}$ was determined using micro-Kjeldahl digestiondistillation method as described by Moberg (2000). Available phosphorus was determined using filtrates extracted by Bray and Kurtz-1 method and determined by spectrophotometer at $884 \mathrm{~nm}$ wavelength following colour developed by molybdenum blue method (Bray and Kurtz, 1945). Extractable S was analyzed using turbidimetric method as described by Moberg (2000). Cation exchange capacity of soil $\left(\mathrm{CEC}_{\text {soil }}\right)$ and exchangeable bases were determined by saturating soil with neutral $1 \mathrm{M} \mathrm{NH}_{4} \mathrm{OAc}$ (ammonium acetate) and adsorbed $\mathrm{NH}_{4}{ }^{+}$were displaced using $1 \mathrm{M} \mathrm{KCl}$ and then determined by Kjeldahl distillation method for estimation of CEC of soil. Exchangeable bases $\left(\mathrm{Ca}^{2+}\right.$, $\mathrm{Mg}^{2+}, \mathrm{Na}^{+}$and $\mathrm{K}^{+}$) were measured by atomic absorption spectrophotometer (AAS) (Thomas, 1982). Total exchangeable bases (TEB) were calculated as sum of exchangeable bases $\mathrm{Ca}^{2+}, \mathrm{Mg}^{2+}, \mathrm{K}^{+}$and $\mathrm{Na}^{+}$. DTPA extractable micronutrients $(\mathrm{Zn}, \mathrm{Mn}, \mathrm{Fe}$ and $\mathrm{Cu})$ were determined using procedure described by Lindsay and Norvell (1978). Total elemental composition (oxides) was determined as follows: Samples were ground to particle size $\leq 177 \mu \mathrm{m}$ using swing mill pulverizer. Powdered samples were pressed into XRF sample cups 
and mounted with PANalytical B.V. X-Ray filmpolyester PETP (Polyethylene Terephthalate Polyester), and then elemental oxides were measured by PANalytical, Minipal 4 Energy Dispersive X-Ray Fluorescence Spectrometer (ED-XRF) Model PW4030/45B.

\section{Soil classification}

Using field and laboratory analytical data on Mvumi pedon, soil classification was done using USDA Soil Taxonomy (Soil Survey Staff, 2014) and World Reference Base for Soil Resources (IUSS Working Group WRB, 2015).

\section{Results and discussion}

\section{Soil morphological characteristics}

Key morphological properties of studied pedon are summarized in Table 1 . The pedon was very deep $(>150 \mathrm{~cm})$ and moderately well drained to somewhat poorly drained (FAO, 2006). It had very dark grey clays, with strong granular topsoil over weak coarse angular and wedge-shaped subsoil. Soil horizon boundaries were clear with smooth horizon topography. Soil pores were common and well distributed within the profile. Roots were distributed throughout profile depth with abundance decreasing with increasing depth. Key pedogenic features described in the pedon are the very well developed slickensides, very deep wide cracks and the wedge-shaped structural aggregates all of which affirming that the soil is rich in swelling type of silicate clay minerals typical of Vertisols. Hence, the dominant pedogenic processes responsible for pedogenesis in the study area are shrinking and swelling, and pedoturbation.

\section{Physical characteristics}

\section{Soil moisture characteristic curves}

Soil moisture retention characteristics of Mvumi pedon are presented in Fig.3. The curves show that, there is gradual decrease in moisture as suction potential increases in all horizons. The lower horizon retained more water followed by mid horizon and upper horizon. Soil moisture characteristic curves are strongly affected by soil texture. When clay content increases, ability of soil to retain water increases at any particular matric potential and the more gradual is the slope of the curves (Hillel, 2007). Thus lower water retention in upper horizon is contributed by its relatively higher sand content and lower clay content (Table 2).

Table 1. Typical morphological characteristics of Mvumi pedon in Kilosa District, Morogoro Region, Tanzania

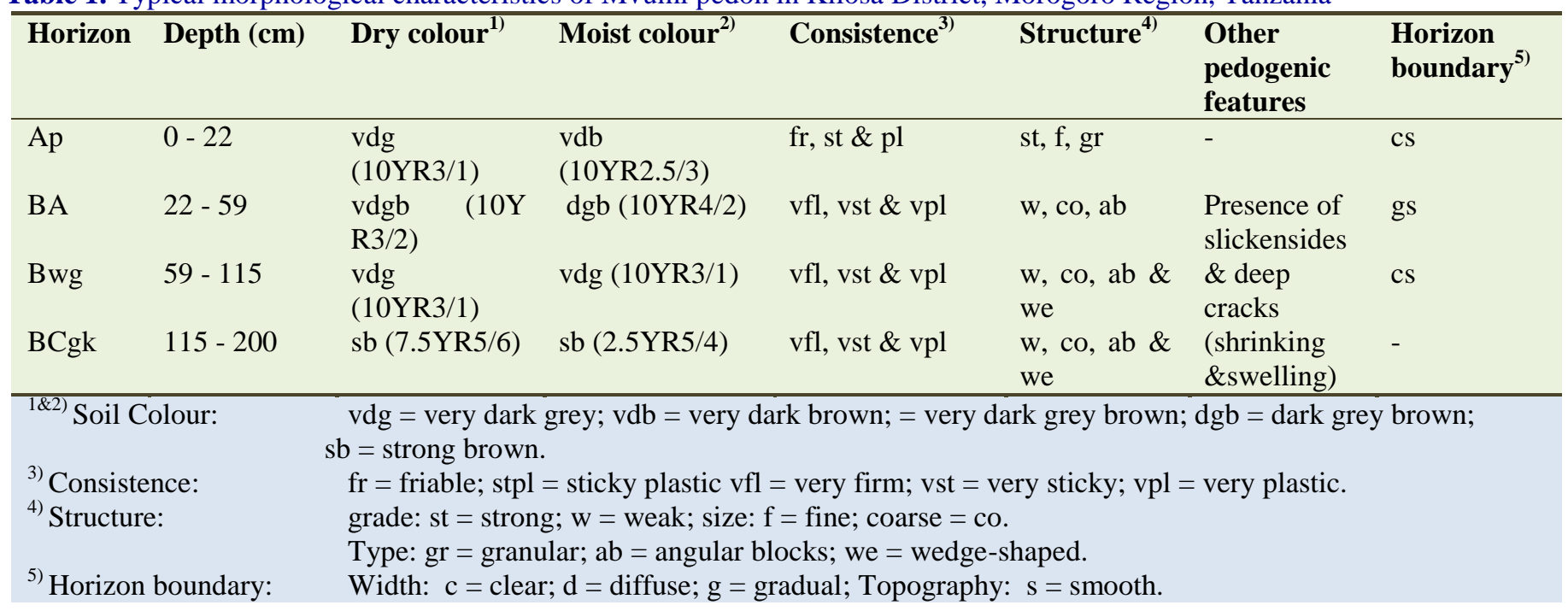

\section{Soil texture}

Results of particle size distribution of studied pedon are shown in Table 2. The pedon had clayey texture throughout its profile depth. Clay content generally increased with depth. The surface horizon (Ap) had the least amount of clay and highest content of sand. Horizons BA and Bwg had same amount of clay which was higher than in the topsoil. The lowermost horizon (BCkg) had slightly lower clay content than the mid 
horizons (BA and Bwg) but higher than in the topsoil. The generally high clay content throughout the pedon is very important as far as paddy rice cultivation is concerned because it helps to minimize percolation of water (Smith and Dilday, 2003).

\section{Bulk density and soil moisture content}

Bulk density (BD) values of studied pedon are shown in Table 2. According to Hazelton and Murphy (2007), the topsoil $\mathrm{BD}$ is rated as medium while the subsoil BD is high. Bulk density is important physical properties of soils which is used as a measure of soil compactness and hence root penetration, soil structure and soil aeration.

According to Hazelton and Murphy (2007) topsoil is rated as being somehow too compacted but the values are below the critical value of $1.4 \mathrm{~g} \mathrm{~cm}^{-3}$ for root growth. Thus, root penetration is not restricted in this horizon whereas mid horizons are highly compacted and are above the critical value for root growth implying that root penetration is highly restricted in these horizons.

Table 2. Physical properties of Mvumi pedon in Kilosa District, Morogoro Region, Tanzania.

\begin{tabular}{lllll}
\hline Horizon & Ap & BA & Bwg & BCkg \\
\hline Soil depth (cm) & $0-22$ & $22-59$ & $59-115$ & $115-200$ \\
Sand \% & 43 & 31 & 29 & 35 \\
Silt \% & 7 & 3 & 5 & 3 \\
Clay \% & 50 & 66 & 66 & 62 \\
Textural class & Clay & Clay & Clay & Clay \\
Silt/clay & 0.14 & 0.05 & 0.08 & 0.05 \\
Bulk density (g/cc) & 1.34 & 1.78 & 1.68 & Nd \\
Penetration resistance $\left(\mathrm{kg} \mathrm{cm}^{-2}\right)$ & 3.81 & 43.55 & 64.68 & 4.35 \\
\hline nd = not determined. & & &
\end{tabular}

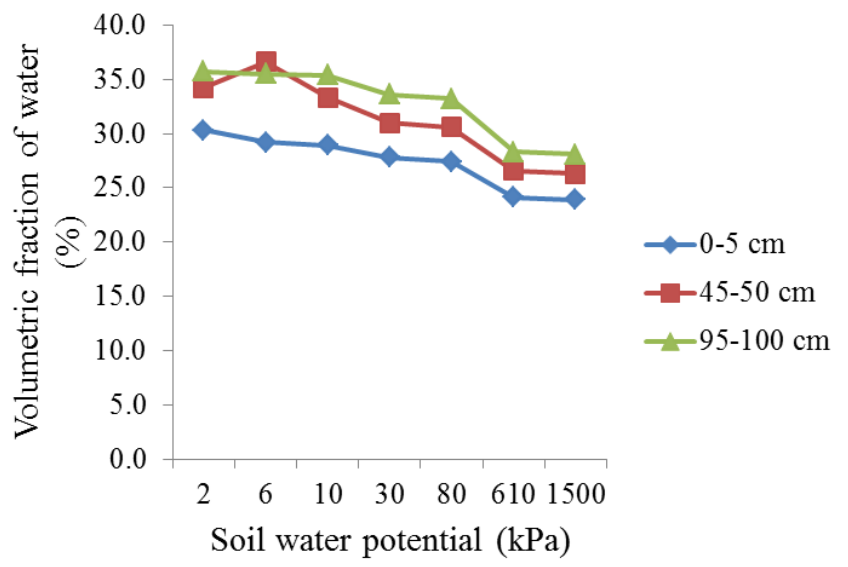

Fig. 3: Moisture retention characteristic curves of Mvumipedon in Kilosa District, Morogoro Region, Tanzania.

\section{Penetration resistance}

Penetration resistance of the four horizons of the studied pedon is presented in Table 2. The topsoil and lowermost horizons had lower penetration resistance (3.81 and $4.35 \mathrm{~kg} \mathrm{~cm}^{-2}$ respectively) than the mid horizons (43.55 and $64.68 \mathrm{~kg} \mathrm{~cm}^{-2}$ ). Hazelton and Murphy (2007) classified penetration resistance in respect to degree of soil consolidations as follows: $<5.1$ $\mathrm{kg} \mathrm{cm}$ as loose consolidated, $5.1-12.75 \mathrm{~kg} \mathrm{~cm}^{-2}$ as medium consolidated, $12.75-20.40 \mathrm{~kg} \mathrm{~cm}^{-2}$ as dense, $20.40-30.60 \mathrm{~kg} \mathrm{~cm}^{-2}$ as very dense and $>30.60 \mathrm{~kg} \mathrm{~cm}^{-2}$ as extremely dense. According to this classification the topsoil and lowermost horizons are loose consolidated and do not affect root growth whereas the mid horizons are extremely dense and root growth in these horizons ceases. These results support the results of bulk density in section 4.1.2.3 which indicated that the upper horizon is not much compacted like the mid horizons. For example Kebeney et al. (2015) reported low penetration resistance in top soils which was attributed to low bulk density and reduced metric potential.

\section{Chemical properties}

\section{Soil pH}

Results of soil $\mathrm{pH}$ in water and in $\mathrm{KCl}$ of the studied Mvumi pedon are presented in Table 3. The $\mathrm{pH}$ of this pedon increases down the profile was an acidic upper horizon and alkaline lower horizon. Low $\mathrm{pH}$ in the upper horizon than in the lower horizon is due to low amount of bases in upper horizon than in lower horizon as shown in Table 5. This situation might have been caused by leaching of the bases $(\mathrm{Ca}, \mathrm{Mg}, \mathrm{K}$, and $\mathrm{Na})$ down the profile hence reducing its amount in upper horizon. 
Table 3. Some chemical properties of the studied pedon at Mvumi, Kilosa District, Morogoro Region, Tanzania.

\begin{tabular}{llllllllll}
\hline Horizon & $\begin{array}{l}\text { Soil depth } \\
(\mathbf{c m})\end{array}$ & $\begin{array}{l}\text { Soil } \mathbf{~ H H} \\
\mathbf{H}_{\mathbf{2}} \mathbf{O}\end{array}$ & $\mathbf{K C l}$ & $\begin{array}{l}\mathbf{O C} \\
\text { \% }\end{array}$ & $\mathbf{O M}$ & $\mathbf{N}$ & $\begin{array}{l}\text { C/N } \\
\text { ratio }\end{array}$ & $\begin{array}{l}\text { Avail. P } \\
\mathbf{m g ~ k g}^{-1}\end{array}$ & Extr. S \\
\hline Ap & $0-22$ & 5.48 & 4.34 & 2.58 & 4.45 & 0.25 & 10.3 & 4.280 & 14.06 \\
BA & $22-59$ & 6.72 & 5.39 & 0.57 & 0.98 & 0.13 & 4.4 & 0.075 & 12.99 \\
Bwg & $59-115$ & 7.16 & 6.22 & 0.29 & 0.50 & 0.14 & 2.1 & 0.007 & 28.54 \\
BCgk & $115-200$ & 8.34 & 7.46 & 0.16 & 0.28 & 0.07 & 2.3 & 0.001 & 37.76 \\
\hline
\end{tabular}

\section{Soil organic carbon, total nitrogen and $\mathrm{C}: \mathrm{N}$ ratio}

Results on organic carbon and organic matter of the studied pedon are presented in Table 3. There is a decrease in organic matter and organic carbon with increase in depth. The topsoil had high organic carbon and organic matter than mid and lower horizons. Total nitrogen in the studied pedon ranged from 0.07 to 0.25 $\%$ in lower and upper horizon respectively. According to Landon (1991), this range of $\mathrm{N}$ is rated as low. Low nitrogen in this pedon could be due to low organic matter content. It was further observed that, like organic carbon, $\mathrm{N}$ was decreasing with increasing depth with higher values in upper horizon than lower horizons. Higher organic matter and nitrogen in upper horizon than in mid and lower horizons could have been contributed by anthropogenic activities where farmers tend to leave rice straw in the farms after harvesting and application of nitrogenous fertilizers such as urea enriches the soil with nitrogen.

\section{Available phosphorus}

Results on available phosphorus of the studied pedon are presented in Table 3. It was observed that available phosphorus ranged from 0.001 to $4.28 \mathrm{mg} \mathrm{kg}^{-1}$. According to Landon (1991) categorization of $\mathrm{P}$ in soils, the studied pedon had very low available $\mathrm{P}$ in all horizons. Also it was observed that the amount of available $\mathrm{P}$ decreases with increasing profile depth. Decrease in $\mathrm{P}$ with depth can be due to decrease in organic matter content with depth. Organic matter plays a key role in $\mathrm{P}$ availability due to its ability to coat aluminium and iron oxides, which reduces $\mathrm{P}$ sorption (Debicka et al., 2015).

\section{Extractable sulphur}

Sulphur content of the studied pedon ranged from 12.99 to $37.76 \mathrm{mg} \mathrm{S} \mathrm{kg}^{-1}$ (Table 3). The content of Sulphur varied among the horizons of the studied pedon with the trend $\mathrm{BA}<\mathrm{Ap}<\mathrm{Bwg}<\mathrm{BCgk}$. According to Horneck (2011) classification of sulphur in soil, Ap and BA horizons had medium sulphur content whereas Bwg and $\mathrm{BCgk}$ had high sulphur content.

\section{Exchangeable bases and cation exchange capacity (CEC)}

Amounts of exchangeable bases $(\mathrm{Ca}, \mathrm{Mg}, \mathrm{K}$, and $\mathrm{Na})$, total exchangeable bases (TEB) and base saturation percent (BS \%) of studied pedon is presented in Table 4. $\mathrm{Ca}, \mathrm{Mg}$ and $\mathrm{Na}$ were increasing with depth while $\mathrm{K}$ was decreasing. Increase of $\mathrm{Ca}, \mathrm{Mg}$ and $\mathrm{Na}$ with depth could be due to the leaching of these bases hence concentrating them in the lower horizons. Also TEB and $\mathrm{BS} \%$ increased with depth with highest values in Bwg. Leaching of bases is the likely explanation for this scenario. BS\% in the studied pedon ranged from 50.2 to $95.3 \%$. BS\% is an indicator of extent of leaching of bases. According to Metson (1961) the Ap horizon is moderately leached, whereas $\mathrm{BA}, \mathrm{Bwg}$ and $\mathrm{BCgk}$ are very weakly leached.

Cation exchange capacity (CEC) of the studied pedon ranged from $38 \mathrm{cmol}(+) \mathrm{kg}^{-1}$ to $40.92 \mathrm{cmol}(+) \mathrm{kg}^{-1}$ (Table 4). According to Metson (1961) rating of CEC, all horizons have high CEC. High CEC is due to high clay content in this pedon. $\mathrm{CEC}_{\text {clay }}$ of the four horizons are shown in Table $4 . \mathrm{CEC}_{\text {clay }}$ is used as a rough guide to clay mineralogy. According to Shaw et al. (1998) all the horizons of studied pedon have clay mineralogy dominated by smectite which is a 2:1 silicate clay mineral.

\section{Soil micronutrients}

Four important micronutrients namely $\mathrm{Cu}, \mathrm{Mn}, \mathrm{Fe}$ and $\mathrm{Zn}$ were analyzed and the results are presented in Table 4. $\mathrm{Cu}$ ranged from 1.86 to $6.69 \mathrm{mg} \mathrm{kg}^{-1}, \mathrm{Mn}$ ranged from 2.57 to $26.91 \mathrm{mg} \mathrm{kg}^{-1}$, Fe ranged from 10.99 to 398.98 $\mathrm{mg} \mathrm{kg}$ and $\mathrm{Zn}$ ranged from 0.13 to $2.02 \mathrm{mg} \mathrm{kg}^{-1}$. According to Landon (1991) rating of micronutrients, $\mathrm{Cu}, \mathrm{Mn}$ and $\mathrm{Fe}$ were high in all horizons, whereas $\mathrm{Zn}$ was low. Low $\mathrm{Zn}$ in this pedon might have been contributed by the flooded conditions which tend to 
reduce Zn solubility (Smith and Dilday, 2003). It was further noted that $\mathrm{Cu}, \mathrm{Mn}$ and $\mathrm{Fe}$ decreased with increasing depth. The decrease of these micronutrients could be due to the increasing soil $\mathrm{pH}$. Fe becomes more available in low $\mathrm{pH}$ soils and decrease when soil becomes alkaline. $\mathrm{Cu}$ and $\mathrm{Mn}$ are more available at $\mathrm{pH}$ of 5 to 6.5 and decrease when $\mathrm{pH}$ is below 5 or above 6.5 .

\section{Soil nutrient balance}

Nutrient ratios $(\mathrm{Ca} / \mathrm{TEB}, \mathrm{Ca} / \mathrm{Mg}, \mathrm{Mg} / \mathrm{K}$ and \% $\mathrm{K} / \mathrm{TEB})$ of each horizon of the studied pedon are presented in Table 5. $\mathrm{Ca} / \mathrm{Mg}$ ratio ranged from 0.88 to 1.39 and $\mathrm{Mg} / \mathrm{K}$ ratio ranged from 17.66 to 79.09 . According to Msanya et al. (2001), the $\mathrm{Ca} / \mathrm{Mg}$ ratio ranges of 2 to 4 and $\mathrm{Mg} / \mathrm{K}$ in the range of 1 to 4 are considered favourable for most crops. According to this rating it is observed in this profile that, $\mathrm{Ca} / \mathrm{Mg}$ ratio is below the optimum range in all horizons while the $\mathrm{Mg} / \mathrm{K}$ ratio is above the optimum range in all horizons. Low ratio of $\mathrm{Ca} / \mathrm{Mg}$ observed in this pedon can limit the uptake of $\mathrm{Mg}$ by plants. $\mathrm{Mg} / \mathrm{K}$ ratio in this profile are very high, this imply that $\mathrm{Mg}$ was very high and can lead to nutrient imbalance and toxicity. Percentage of K/TEB and $\mathrm{Ca} / \mathrm{TEB}$ of the studied pedon ranged from $0.62 \%$ to $2.29 \%$ and from 0.45 to 0.56 respectively. Only the Ap horizon had the percentage K/TEB ratio above $2 \%$ which is favourable for most crops, other horizons had $\% \mathrm{~K} / \mathrm{TEB}$ below 2\%. According to Landon (1991), $\mathrm{Ca} / \mathrm{TEB}$ ratios in Ap and BA horizons will negatively affect uptake of other bases particularly $\mathrm{Mg}$ and $\mathrm{K}$ as they are above 0.5. Horizons Bwg and BCgk had favourable $\mathrm{Ca} / \mathrm{TEB}$ ratios.

Table 4. Exchangeable bases, CEC and micronutrient content of Mvumi soil pedon in Kilosa District, Morogoro Region, Tanzania.

\begin{tabular}{|c|c|c|c|c|c|c|c|c|c|c|c|c|c|}
\hline \multirow{2}{*}{ Horizon } & \multirow{2}{*}{$\begin{array}{l}\text { Soil depth } \\
\text { (cm) }\end{array}$} & \multicolumn{5}{|c|}{ Exchangeable bases cmol (+) $\mathrm{kg}^{-1}$} & \multirow{2}{*}{\multicolumn{2}{|c|}{$\begin{array}{l}\mathrm{CEC}_{\text {soil }} \mathrm{CEC}_{\text {clay }} \\
\mathrm{cmol}(+) \mathrm{kg}^{-1}\end{array}$}} & \multirow{2}{*}{ BS\% } & \multicolumn{4}{|c|}{ Micronutrients $\left(\mathrm{mg} \mathrm{kg}^{-1}\right)$} \\
\hline & & $\mathbf{C a}$ & Mg & $\mathbf{K}$ & $\mathrm{Na}$ & TEB & & & & $\mathbf{C u}$ & Mn & $\mathrm{Fe}$ & Zn \\
\hline $\mathrm{A}_{1}$ & $0-22$ & 11.5 & 8.3 & 0.47 & 0.26 & 20.53 & 40.92 & 81.84 & 5 & 6.69 & 26.91 & 398.98 & 2.02 \\
\hline BA & & 14.2 & 13.3 & 0.24 & 0.34 & 28.08 & 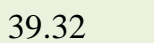 & 59 & & 2.85 & 12.63 & 30.90 & 0.13 \\
\hline Bwg & $59-1$ & 16.4 & 18.6 & 0.25 & 0.98 & 36.23 & 38.00 & 57.58 & 95. & 3.13 & 9.51 & 23.16 & 0.38 \\
\hline BCgk & $115-200$ & 16.4 & 17.4 & 0.22 & 1.22 & 35.24 & 38.82 & 62.61 & 90.8 & 1.86 & 2.57 & 10.99 & 0.63 \\
\hline
\end{tabular}

Table 5. Soil nutrient ratios of Mvumi soil pedon in Kilosa District, Morogoro Region, Tanzania.

\begin{tabular}{llllll}
\hline Horizon & Soil depth $(\mathbf{c m})$ & $\mathbf{C a} / \mathbf{T E B}$ & $\mathbf{C a} / \mathbf{M g}$ & $\mathbf{M g} / \mathbf{K}$ & \% $\mathbf{~} / \mathbf{T E B}$ \\
\hline Ap & $0-22$ & 0.56 & 1.39 & 17.66 & 2.29 \\
BA & $22-59$ & 0.51 & 1.07 & 55.42 & 0.85 \\
Bwg & $59-115$ & 0.45 & 0.88 & 74.40 & 0.69 \\
BCgk & $115-200$ & 0.47 & 0.94 & 79.09 & 0.62 \\
\hline TEB = total exchangeable bases & & &
\end{tabular}

Total elemental composition and chemical index of alteration

Results on total elemental composition and chemical index of alteration of the studied pedon are presented in Table 6. $\mathrm{SiO}_{2}$ was the most abundant oxide in this pedon followed by $\mathrm{Fe}_{2} \mathrm{O}_{3}$ and $\mathrm{Al}_{2} \mathrm{O}_{3}$. Other oxides i.e. $\mathrm{K}_{2} \mathrm{O}$, $\mathrm{CaO}, \mathrm{TiO}_{2}, \mathrm{MnO}, \mathrm{P}_{2} \mathrm{O}_{5}, \mathrm{MgO}$ and $\mathrm{Na}_{2} \mathrm{O}$ were in very low concentration i.e. below 4\%.Higher concentration of $\mathrm{SiO}_{2}$ in the pedon infers the dominance of quartz minerals in the area whereas the observed concentration of $\mathrm{Fe}_{2} \mathrm{O}_{3}$ suggests the presence of Fe-containing minerals such as hematite and goethite. Chemical Index of Alteration (CIA) values of the studied pedon ranged from $78.52 \%$ to $84.30 \%$. CIA is used as a measure of degree of weathering of minerals (Nesbitt and Young, 1982). Low CIA values indicate low weathering or unaltered minerals whereas high values indicated high degree of weathering. CIA values helps to predict the age of formation of soil, the smaller the CIA value, the younger the soils are in terms of degree of weathering and age of formation (Uwitonze et al., 2016). Therefore, the results of this study shows that the upper horizon (Ap) is less weathered compared to other horizons while horizon Bwg is highly weathered.

\section{Soil classification}

Classification of the soils of the studied area was done based on the diagnostic horizons and other diagnostic features of the studied pedon as summarized in Table 7. This pedon was located on a flat area (slope $<1 \%$ ), and was characterized as moderately alkaline and very deep with clayey texture, deep wide cracks and wedge-shaped aggregates. Slickensides and gilgai micro-relief were observed in this pedon. According to USDA Soil 
Taxonomy this pedon has an Ochric epipedon and Calcic horizon whereas according to World Reference Base for Soil Resources (WRB) it has Vertic and Calcic horizon. Therefore, this pedon (Mvumi pedon), is classified as
Ustic Endoaquerts and Haplic Vertisols (Hypereutric, Gilgaic, Gleyic, Mazic) in USDA Soil Taxonomy and WRB, respectively. According to Fageria (2014), these soils are favourable for rice growth.

Table 6. Total elemental composition of Mvumi soil pedon in Kilosa District, Morogoro Region, Tanzania.

\begin{tabular}{lllllllllllll}
\hline \multirow{2}{*}{ Horizon } & $\begin{array}{l}\text { Soil depth } \\
(\mathbf{c m})\end{array}$ & $\mathbf{S i O}_{\mathbf{2}}$ & $\mathbf{A l}_{\mathbf{2}} \mathbf{O}_{\mathbf{3}}$ & $\mathbf{F e}_{\mathbf{2}} \mathbf{O}_{\mathbf{3}}$ & $\mathbf{K}_{\mathbf{2}} \mathbf{O}$ & $\mathbf{C a O}$ & $\mathbf{T i O}_{\mathbf{2}}$ & $\mathbf{M n O}$ & $\mathbf{P}_{2} \mathbf{O}_{\mathbf{5}}$ & $\mathbf{M g O}$ & $\mathbf{N a}_{\mathbf{2}} \mathbf{O}$ & $\mathbf{C I A}$ \\
\hline Ap & $0-22$ & 50.50 & 16.00 & 23.73 & 2.12 & 2.24 & 3.23 & 0.16 & 0.00 & 0.014 & 0.017 & 78.52 \\
Bwg & $59-115$ & 46.80 & 19.00 & 25.22 & 1.77 & 1.76 & 3.41 & 0.13 & 0.00 & 0.016 & 0.008 & 84.30 \\
BCgk & $115-200$ & 46.30 & 19.00 & 25.71 & 1.82 & 2.13 & 3.33 & 0.15 & 0.00 & 0.029 & 0.011 & 82.75 \\
\hline
\end{tabular}

$\mathrm{CIA}=$ Chemical index of alteration $=\left\{\mathrm{Al}_{2} \mathrm{O}_{3} /\left(\mathrm{Al}_{2} \mathrm{O}_{3}+\mathrm{K}_{2} \mathrm{O}+\mathrm{Na}_{2} \mathrm{O}+\mathrm{CaO}\right)\right\} * 100$

Table 7. Summary of diagnostic horizons and features and classification of Mvumi soil pedon in Kilosa District, Morogoro Region, Tanzania.

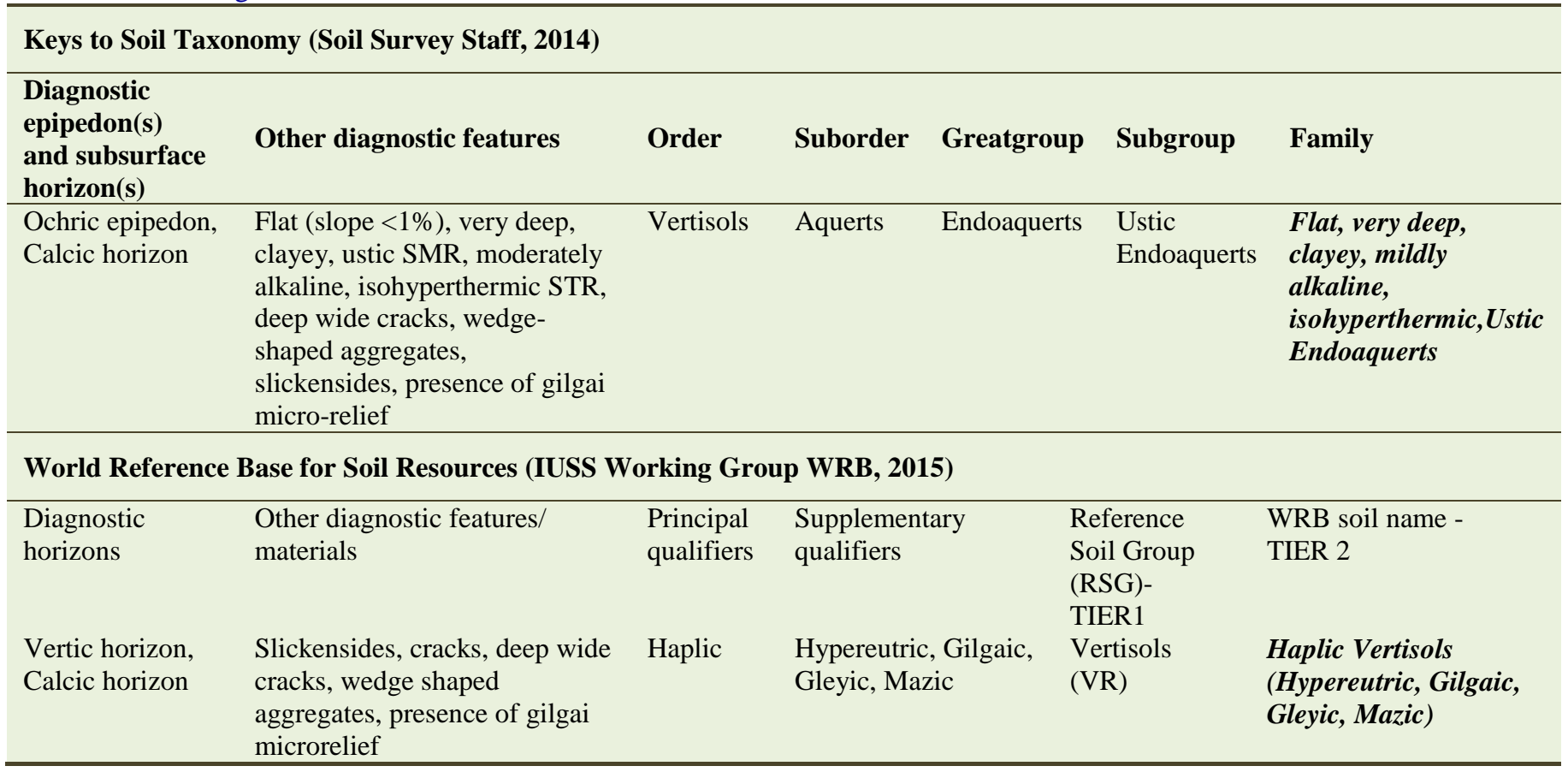

\section{Soil fertility status of rice growing areas in Mvumi} Village based on topsoil data

\section{Soil texture}

Soil particle size (texture) of the studied sites is shown in Table 8. All sites had sandy clay texture except site S3 which had clay texture. These textural classes (sandy clay and clay) are favourable for growth of paddy rice as they have sufficient amount of clay that can hold water for long period of time as paddy rice demands soils which can retain moisture (Moormann and Breemen, 1978). Sandy soils and coarser loamy soils are less productive for rice production when compared to finer textured soils. Moreover, more water and nutrients especially nitrogen are required for rice in sandy and coarser loamy soils than in finer textured soils, which makes the management more costly (Moormann and Breemen, 1978).

\section{Soil pH}

Soil $\mathrm{pH}$ of the studied soils ranged from 5.2 to 7.4 as shown in Table 8. According to categorization of soil $\mathrm{pH}$ by Landon (1991), these soils have low to high $\mathrm{pH}$. This range of soil $\mathrm{pH}$ is suitable for rice growth as it is within the range of 5.0 -7.5 as reported by Smith and Dilday (2003).Soil pH within the scheme is high compared to the areas outside the scheme. High soil $\mathrm{pH}$ of the scheme area could have been contributed by the 
quality of irrigation water. High $\mathrm{pH}$ irrigation water contributes to increased soil pH (Tacker, 2003).

\section{Organic carbon}

Results on organic carbon and organic matter content of the studied soils are also presented in Table 8 . According to Landon (1991), the amount of organic carbon in all sites is very low. Organic matter has an effect on the availability of nutrients such as nitrogen, phosphorus and CEC. Low organic matter content reduces the availability of these nutrients which are essential for plant growth.

\section{Available phosphorus}

Phosphorus is one of the essential nutrients for rice growth and productivity. Available phosphorus which is the phosphorus that can be accessed by plant was determined by two methods namely Bray- 1 for acid soils and Olsen for alkaline soils. Bray-1 P ranged from 1.54 to $5.79 \mathrm{mg} \mathrm{P} \mathrm{kg}^{-1}$ soil and was classified as very low to low. Whereas Olsen $\mathrm{P}$ ranged from 8.61 to $14.82 \mathrm{mg} \mathrm{P}$ $\mathrm{kg}^{-1}$ and these were classified as medium to high $\mathrm{P}$ concentration. Phosphorus was low in areas outside the scheme whereas it was high in areas within the scheme (Table 8). Phosphorus is highly affected by $\mathrm{pH}$. $\mathrm{P}$ availability decreases as soils become acidic and in calcareous soils (Tisdale et al., 1993). Therefore, the high $\mathrm{P}$ observed within the scheme can be attributed to high $\mathrm{pH}$ in these areas.

\section{Total nitrogen}

Nitrogen is a problem in many cultivated areas. In the studied areas, nitrogen ranged from $0.06 \%$ to $0.19 \%$ (Table 8). These values are classified as very low to low (Landon, 1991). Low nitrogen in these areas could have been contributed by low organic matter content, continuous cultivation of rice in the area which does not permit accumulation of $\mathrm{N}$ as well as many chemical, biochemical and microbial transformation of $\mathrm{N}$ in the flooded soils (Smith and Dilday, 2003). Therefore, there is need to apply nitrogenous fertilizers so as to facilitate growth and subsequently improve yield of rice in these areas.

\section{Extractable sulphur}

Sulphur content for the eight studied areas ranged from 15.92 to $31.52 \mathrm{mg} \mathrm{S} \mathrm{kg}^{-1}$ (Table 8). Horneck (2011) classified sulphur as follows: 0 - $5 \mathrm{mg} \mathrm{kg}^{-1}$ low, 5 - 20 $\mathrm{mg} \mathrm{kg}{ }^{-1}$ medium and $>20 \mathrm{mg} \mathrm{kg}^{-1}$ as high. In view of this, sulphur is not a big problem in the studied sites as it is high in six sites and medium in the remaining two sites.

\section{Exchangeable bases}

\section{Calcium}

Calcium content of the tested soils is shown in Table 9. Calcium ranged from 5.59 to $12.51 \mathrm{cmol}(+) \mathrm{kg}^{-1}$, values that are rated as moderate to high calcium by Metson (1991). It was observed that sites within the scheme have high calcium than the sites outside the scheme. This variation is due to difference in $\mathrm{pH}$ where inside the scheme there was high $\mathrm{pH}$ than in sites outside the scheme.

\section{Magnesium}

Exchangeable magnesium in the studied sites ranged from 3.67 to $8.63 \mathrm{cmol}(+) \mathrm{kg}^{-1}$ (Table9). Metson (1991) rated $\mathrm{Mg}$ as follows: $0.3-1$ as low, 1-3 as moderate, 3-8 as high and $>8$ as very high. According to this rating all the studied sites had high Mg content.

\section{Potassium}

Results on exchangeable potassium in the studied soils are presented in Table 9. According to Metson (1991) categorization of $\mathrm{K}$ all studied sites had low $\mathrm{K}$ content except site S2 which had moderate K. This shows that K is a problem in these areas and it should be applied so as to boost yield of rice. Uddin et al. (2013) reported an increase in plant height, number of tillers, size of panicles and yield of rice upon application of $\mathrm{K}$.

\section{Sodium}

Amount of sodium in the studied soils varies from 0.10 to $0.37 \mathrm{cmol}(+) \mathrm{kg}^{-1}$ (Table 9). According to Metson (1991), all soils had low sodium content. Soils with high amount of sodium are considered as alkaline or sodic soils and are not good for growth of crops as they are salt affected soils.

\section{Cation exchange capacity (CEC)}

CEC of the studied sites ranged from 15.2 to $23 \mathrm{cmol}$ (+) $\mathrm{kg}^{-1}$ (Table 9). These are classified as medium according to Landon (1991). CEC is highly affected by 
organic matter and clay content of the soil. Due to low organic matter of these soils the observed value of CEC comes mostly from the clay fraction. CEC is very important as it reflects the ability of the soil to hold nutrients. It is a very important soil property influencing soil structure stability, nutrient availability, soil $\mathrm{pH}$ and the soil's reaction to fertilizers and other ameliorants (Hazleton and Murphy, 2007).

Table 8. Some chemical and physical properties of topsoils from study sites in Mvumi Village, Kilosa District, Tanzania.

\begin{tabular}{|c|c|c|c|c|c|c|c|c|c|c|c|c|}
\hline Site & & Location & $\begin{array}{l}\mathrm{pH}_{\text {wate }} \\
\mathrm{r}\end{array}$ & \multicolumn{2}{|c|}{$\frac{\text { Avail. P S }}{\mathrm{mg} \mathrm{kg}^{-1}}$} & $\begin{array}{l}\mathrm{N} \\
\% \\
\end{array}$ & $\overline{\mathrm{OC}}$ & $\mathbf{O M}$ & Sand & Silt & Clay & $\begin{array}{l}\text { Textural } \\
\text { class }\end{array}$ \\
\hline - in & S1 & $06^{\circ} 36^{\prime} 0.2^{\prime \prime} \mathrm{S}$ and $37^{\circ} 13^{\prime} 35.2^{\prime \prime} \mathrm{E}$ & 6.9 & 8.87 & 27.92 & 0.06 & 0.53 & 0.91 & 46.96 & 3.28 & 49.76 & Sandy clay \\
\hline \multirow[t]{3}{*}{ scheme } & $\mathrm{S} 2$ & $06^{\circ} 36^{\prime} 7.8^{\prime \prime} \mathrm{S}$ and $37^{\circ} 13^{\prime} 31.6^{\prime \prime} \mathrm{E}$ & 7.2 & 8.61 & 21.33 & 0.10 & 0.84 & 1.45 & 54.96 & 5.28 & 39.76 & San \\
\hline & S3 & $06^{\circ} 36^{\prime} 15.3^{\prime \prime} \mathrm{S}$ and $37^{\circ} 13^{\prime} 31.5^{\prime \prime} \mathrm{E}$ & 7.4 & 14.82 & 17.02 & 0.10 & 0.95 & 1.64 & 40.96 & 7.28 & 51.76 & Clay \\
\hline & S4 & $06^{\circ} 36^{\prime} 13.7^{\prime \prime} \mathrm{S}$ and $37^{\circ} 13^{\prime} 33.9^{\prime \prime} \mathrm{E}$ & 7.1 & 10.94 & 20.12 & 0.11 & 0.88 & 1.52 & 48.96 & 5.28 & 45.76 & Sandy clay \\
\hline \multirow{4}{*}{$\begin{array}{l}\text { Outside } \\
\text { the } \\
\text { scheme }\end{array}$} & S5 & - & 6.4 & 4.63 & 20.78 & 0.10 & 1.14 & 1.97 & 54.96 & 3.28 & 41.76 & Sandy clay \\
\hline & S6 & $06^{\circ} 36^{\prime} 19.2^{\prime \prime} \mathrm{S}$ and $37^{\circ} 13^{\prime} 24.2^{\prime \prime} \mathrm{E}$ & 5.2 & 1.54 & 31.52 & 0.17 & 1.75 & 3.02 & 46.96 & 7.28 & 45.76 & Sandy clay \\
\hline & S7 & $06^{\circ} 36^{\prime} 2.9^{\prime \prime} \mathrm{S}$ and $37^{\circ} 13^{\prime} 32.4^{\prime \prime} \mathrm{E}$ & 5.5 & 3.58 & 22.08 & 0.13 & 1.14 & 1.97 & 52.96 & 5.28 & 41.76 & Sandy clay \\
\hline & S8 & $06^{\circ} 35^{\prime} 55.9^{\prime \prime} \mathrm{S}$ and $37^{\circ} 13^{\prime} 34.2^{\prime \prime} \mathrm{E}$ & 5.6 & 5.79 & 15.92 & 0.19 & 1.22 & 2.10 & 48.96 & 7.28 & 43.76 & Sandy clay \\
\hline
\end{tabular}

Table 9. Micronutrient contents and exchangeable bases of the sites in Mvumi Village, Kilosa District, Tanzania.

\begin{tabular}{|c|c|c|c|c|c|c|c|c|c|}
\hline \multirow{2}{*}{ Site } & $\mathbf{C a}$ & $\mathrm{Mg}$ & $\mathbf{K}$ & $\mathbf{N a}$ & CEC & $\mathbf{Z n}$ & $\mathbf{C u}$ & $\mathbf{F e}$ & Mn \\
\hline & \multicolumn{5}{|c|}{$\left[\mathrm{cmol}(+) \mathrm{kg}^{-1}\right]$} & \multicolumn{4}{|c|}{$\left(\mathrm{mg} \mathrm{kg}^{-1}\right)$} \\
\hline S1 & 12.51 & 8.41 & 0.12 & 0.29 & 21.6 & 0.35 & 3.59 & 19.65 & 23.30 \\
\hline S2 & 8.69 & 3.67 & 0.40 & 0.19 & 15.2 & 0.35 & 2.05 & 24.91 & 30.47 \\
\hline S3 & 9.41 & 8.63 & 0.31 & 0.37 & 23 & 0.66 & 3.35 & 60.88 & 62.01 \\
\hline S4 & 10.84 & 5.45 & 0.24 & 0.18 & 21 & 0.55 & 2.99 & 51.23 & 60.57 \\
\hline S5 & 7.74 & 4.01 & 0.24 & 0.11 & 15.2 & 0.66 & 3.59 & 126.32 & 59.14 \\
\hline S6 & 9.65 & 6.40 & 0.24 & 0.10 & 21.6 & 1.11 & 4.30 & 306.14 & 46.24 \\
\hline S7 & 5.59 & 3.84 & 0.15 & 0.12 & 15.2 & 1.17 & 4.42 & 279.82 & 31.90 \\
\hline S8 & 7.74 & 4.51 & 0.24 & 0.15 & 21 & 1.57 & 5.24 & 174.56 & 27.60 \\
\hline
\end{tabular}

\section{Micronutrients}

The amounts of micronutrients in the studied sites are given in Table 9. According to Landon (1991), all micronutrients are rated as very high in all sites except for $\mathrm{Zn}$ in areas within the irrigation scheme. $\mathrm{Zn}$ is observed to be lower in the scheme than in areas outside the scheme. Smith and Dilday (2003) reported that high $\mathrm{pH}$ reduces the availability of $\mathrm{Zn}$ in soils due to flooded condition which reduces $\mathrm{Zn}$ solubility, therefore low $\mathrm{Zn}$ content observed in irrigated areas could have been contributed by relatively high $\mathrm{pH}$ in these areas. $\mathrm{Zn}$ is very important in growth and yield of rice as it helps in cytochrome and nucleotide synthesis, auxin metabolism, chlorophyll production, enzyme activation and maintenance of membrane integrity (Dobermann and Fairhurts, 2000). Considering the roles that $\mathrm{Zn}$ plays in growth and yield of rice, there is a need to apply $\mathrm{Zn}$ fertilizers such as zinc sulphate in these areas so as to supply zinc especially in the scheme where $\mathrm{Zn}$ was observed to be highly deficient.

\section{Conclusions}

The following conclusions were made from the results that were obtained from this study: i. The studied soils are classified as Ustic Endoaquerts and Haplic Vertisols in USDA Soil Taxonomy and WRB respectively. These soil types have characteristics which favour the growth and productivity of paddy rice.

ii. Important nutrients for rice growth and productivity i.e. Nitrogen, Phosphorus and Potassium are deficient in all sampled fields. Micronutrients were adequate except for Zinc which is apparently low. Sites inside the scheme have higher soil $\mathrm{pH}$ and exchangeable bases than sites outside the scheme whereas $\mathrm{P}, \mathrm{Zn}, \mathrm{N}$ and organic carbon are higher in sites outside the scheme than inside the scheme.

\section{Recommendation}

Nitrogen, Phosphorus, Potassium, Sulphur and Zinc that were found to be deficient in the studied area need to be applied so as to improve rice productivity in Mvumi Village.

\section{Conflict of interest statement}

Authors declare that they have no conflict of interest. 


\section{References}

Blake, G. R., Hartge, K. H., 1986. Bulk Density. In: Methods of Soil Analysis, Part 1, $2^{\text {nd }}$ Edn. Agronomy Monograph No. 9. (Ed.: Klute, A.). American Society of Agronomy \& Soil Science Society of America, Madison, Wisconsin. pp.364376.

Bray, R. H., Kurtz, L. T., 1945. Determination of total, organic, and available forms of phosphorus in soils. Soil Sci. 59, 39-45.

Day, P. R. (Ed.), 1965. Particle Fraction and Particle Size Analysis: Methods of Soil Analysis. Blackwell Science Ltd., Oxford. 545p.

Debicka, M., Kocowicza, A., Webera, J., Jamroza, E., 2015. Organic matter effects on phosphorus sorption in sandy soils. Arch. Agron. Soil Sci. 62, 840-855.

Dobermann, A., Fairhurts, T., 2000. Rice Nutrient Disorders and Nutrient Management. Oxford Graphic Printer Pte. Ltd., Oxford. 191p.

Duursma, E. K., Dawson, R. (Eds.), 1981. Marine Organic Chemistry: Evolution, Composition, Interactions and Chemistry of Organic Matter in Seawater. Elsevier, Amsterdam. 521p.

Fageria, N. K., 2014. Mineral nutrition of rice. Kindle Edn. CRC Press, Boca Raton FL. pp.196-200.

FAO, 2006. Guidelines for Soil Description. $4^{\text {th }}$ Edn. Food and Agriculture Organization of the United Nations, Rome. 110p.

Hazelton, P. A., Murphy, B. W., 2007. Interpreting Soil Test Results: What Do All the Numbers Mean?. $2^{\text {nd }}$ Edn. CSIRO publishing, New South Wales, (NSW) Department of Natural Resources, Collingwood, Australia. pp.168-175.

Hillel, D., 2007. Soil in the Environment: Crucible of Terrestrial Life. $1^{\text {st }}$ Edn. Academic Press/Elsevier, Amsterdam. 320p.

Horneck, D. A., Sullivan, D. M., Owen, J. S., Hart, J. M., 2011. Soil Test Interpretation Guide. [http://ir.library.oregonstate.edu/xmlui/bitstream/han dle/1957/22023/ec1478.pdf], site visited on 17 May 2016.

IUSS Working Group WRB, 2015. World Reference Base for Soil Resources 2014, update 2015. International Soil Classification System for Naming Soils and Creating Legends for Soil Maps. World Soil Resources Reports No. 106. FAO, Rome.

Karuma, A. N., Gachene C. K. K., Msanya B. M., Mtakwa P. W., Amuri, N., Gicheru, P. T., 2014. Soil morphology, physico-chemical properties and classification of typical soils of Mwala District, Kenya. Int. J. Plant Soil Sci. 4(2), 156-170.

Kebeney, S. J., Msanya, B. M., Ng'etich, W. K., Semoka, J. M. R., Serrem, C. K., 2015. Pedological characterization of some typical soils of Busia County, Western Kenya: Soil morphology, physicochemical properties, classification and fertility trends. Int. J. Plant Soil Sci. 4, 29-44.

Landon, J. R., 1991. Booker Tropical Soil Manual, Hand Book for Soil Survey and Agricultural Land Evaluation in Tropics and Sub-tropics. Longman Scientific \& Technical Publishers, Essex. 47p.

Lindsay, W. L., Norvell, W. A., 1978. Development of DTPA soil test for $\mathrm{Zn}, \mathrm{Fe}, \mathrm{Mn}$ and $\mathrm{Cu}$. Soil Sci. Soc. Amer. J. 42, 421-428.

McLean, E. O., 1986. Soil pH and lime requirement. In: Methods of Soil Analysis, Part 2: Chemical and Mineralogical Properties (Eds.: Page, A.L., Miller, R. H., Keeny, D. R.). $2^{\text {nd }}$ Edn). Agronomy Monograph No. 9. American Society of Agronomy and Soil Science Society of America, Madison, Wisconsin. pp.199-223.

Metson, A. J., 1961. Methods of Chemical Analysis for Soil Survey Samples. New Zealand Department of Scientific and Industrial Research. 102p.

Moberg, J., 2000. Soil and Plant Analysis Manual. The Royal Verterinary and Agricultural University Chemistry Department, Copenhagen, Denmark. 133p.

Moormann, F. R., Breemen, N. V., 1978. Rice: soil, water, land. International Rice Research Institute, Los Baños, Philippines. 110p.

Msanya, B. M., Munishi, J. A., Amuri, N., Semu, E., Mhoro, L., Malley, Z., 2016. Morphology, genesis, physico-chemical properties, classification and potential of soils derived from volcanic parent materials in selected Districts of Mbeya Region, Tanzania. Int. J. Plant Soil Sci. 10(4), 1-19.

Msanya, B. M., Kaaya, A. K., Araki, S., Otsuka, H., Nyadzi, G. I., 2003. Pedological characteristics, general fertility and classification of some benchmark soils of Morogoro district, Tanzania. Afr. J. Sci. Tech. 4, 101 - 112.

Msanya, B. M., Kimaro, D. N., Kileo, E. P., Kimbi, G. G., Munisi, A. I. M., 2001. Land Resources Inventory and Suitability Assessment for the Production of the Major Crops in the Eastern Part of Morogoro Rural District, Tanzania. Soils and Land Resources of Morogoro Rural and Urban Districts, Vol. 3. Department of Soil Science, Faculty of 
Agriculture, Sokoine University of Agriculture, Morogoro, Tanzania. 69p.

Munsell Color Company, 1992. Munsell Soil Color Charts.Baltimore, Maryland. Lincoln, NE.

Nelson, D. W., Sommers, L. E., 1982. Total organic carbon. In: Methods of Soil Analysis, Part 2. Chemical and Microbiological Properties (Ed.: Page, A. L.). American Society of Agronomy Madison, Wisconsin. pp.539-579.

Nesbitt, H. W., Young, G. M., 1982. Early Proterozoic climates and plate motions inferred from major element chemistry of luttites. Nature. 291, 715717.

Shaw, R. J., Coughlan, K. J., Bell, L. C., 1998. Root zone sodicity. In: Sodic Soils: Distribution, Properties, Management, and Environmental Consequences (Eds.: Sumner, M.E., Naidu, R.). Oxford University Press, New York. pp.95-106.

Smith, C. W., Dilday, R. H., 2003. Rice: Origin, History, Technology, and Production. John Wiley \& Sons, Inc. Hoboken, New Jersey. pp.272-333.

Soil Survey Staff, 2014. Keys to Soil Taxonomy. $12^{\text {th }}$ Edn. United States Department of Agriculture, Natural Resources Conservation Service.

Tacker, P., 2003. Salts Can Cause Problems: Check Quality of Irrigation Water. Delta Farm Press. [http://deltafarmpress.com/salts-can-cause-problems -check-quality-irrigation-water] site visited on 15 May 2016.

Thomas, G. W., 1982. Exchangeable cations. In: Methods of Soil Analysis. Part 2, $2^{\text {nd }}$ Edn. Chemical and Mineralogical Properties, Agronomy Monograph No. 9. (Eds.: Page, L. A., Miller, R. H., Keeney, D. R.). American Society of Agronomy \& Soil Science Society of America, Madison, Wisconsin. pp.595-624.

Tisdale, S. L, Nelson, W. L., Beaton, J. D., 1993. Soil Fertility and Fertilizers. $6^{\text {th }}$ Edn. Prentice Hall, Upper Saddle, New Jersey. pp.305-319.

Uddin, S., Sarkar, M., Rahman, M. 2013. Effect of nitrogen and potassium on yield of dry direct seeded rice cv. NERICA 1 in aus season. Int. J. Agron. Plant Prod. 4(1), 69-75.

United State Department of Agriculture (USDA), 1975. Soil Taxonomy: Basic System of Soil Classification for Making Interpreting Soil Surveys. Soil Concservation Services, Washington DC. 754p.

Uwitonze, P., Msanya, B. M., Mtakwa, P. W., Uwingabire, S., Sirikare, S., 2016. Pedological. Characterization of Soils Developed from Volcanic Parent Materials of Northern Province of Rwanda. Agric. For. Fish. 5(6), 225-236.

\section{How to cite this article:}

Massawe, I. H., Msanya, B. M., Rwehumbiza, F. B., 2017. Pedological characterization and fertility evaluation of paddy soils of Mvumi Village, Kilosa District, Tanzania. Int. J. Curr. Res. Biosci. Plant Biol. 4(4), 49-60. doi: https://doi.org/10.20546/ijcrbp.2017.404.009 